\title{
Penerapan Algoritma Kompresi Pada Sistem Pengaduan Layanan Masyarakat Online
}

\author{
I Gusti Agung Gede Arya Kadyanan \\ Program Studi Teknik Informatika, Fakultas Matematika dan IImu Pengetahuan Alam, \\ Universitas Udayana \\ Kampus Unud Bukit Jimbaran, Indonesia \\ gungde@unud.ac.id
}

\begin{abstract}
Handling complaints is a reciprocal service for the public provided by the government. People who want to make a complaint can make it by dialing the phone number, web, emails and suggestion box provided by the government. Problems encountered in making this complaint include an error in entering/writing the targeted agency, the distance to the suggestion box is far and not real time. The author designed a mobile-based information system for handling public complaints using the android operating system. This public complaint handling application has a feature where the user can choose the agency in accordance with the complaint, the complaint can include pictures, location tags, can see the lates developments of complaint handling in the status of complaints, as well as chat feature that can be used to communicate directly with the Government and the Admin Agencies. Based on the result of test conducted, namely testing using black box method and stress testing, it can be concluded that this application has functioned properly.
\end{abstract}

Keywords: Image, Boxblur Algorithm, Information System, Compression

\section{Introduction}

Dalam kehidupan sehari-hari, banyak terjadi masalah terkait layanan fasilitas umum. Masyarakat yang memiliki banyak keluhan dan mengharapkan segera adanya tindak lanjut dari pemerintah agar seluruh masyarakat mendapatkan kenyamanan yang layak. Oleh karena itu, pemerintah menyediakan sarana bagi masyarakat untuk dapat menyampaikan keluhannya yaitu dengan adanya layanan pengaduan.

Masyarakat yang ingin membuat pengaduan dapat melakukan pengaduan dengan menghubungi nomor telepon, web, email, dan kotak saran yang sudah disediakan pemerintah. Pengaduan yang masuk akan diterima oleh Bagian Organisasi di pemerintahan kemudian akan diteruskan ke Instansi terkait. Masalah yang dihadapi dalam melakukan pengaduan ini adalah masih adanya kesalahan yang dilakukan dalam proses pengaduan seperti kesalahan dalam mencantumkan instansi yang dituju, jarak tempuh menuju kotak saran yang tersedia di masingmasing instansi jauh dari rumah masyarakat, pengaduan dengan kotak saran tidak bersifat real time yang mengakibatkan pengaduan yang disampaikan tidak langsung diproses, dan tidak disertakannya bukti berupa gambar tentang keluhan yang ingin ditindaklanjuti.

Diharapkan sistem ini akan bermanfaat sebagai sarana mempermudah dalam menyampaikan informasi, kritik dan saran secara cepat tanpa mengenal batasan jarak dan waktu, Pemerintah dapat dengan cepat menerima pengaduan yang disampaikan oleh masyarakat, mempermudah dalam proses pendataan dan penanganan pengaduan. Masyarakat tidak perlu lagi menempuh jarak yang cukup jauh untuk dapat membuat sebuah pengaduan dan masyarakat tidak perlu terburu-buru dan mencari waktu luang ditengah kesibukan dan kegiatannya masing-masing.

\section{Reseach Methods / Software Development Life Cycle}

Menurut Supriyanto (2005), metode pengembangan sistem informasi merupakan suatu metode yang digunakan untuk melakukan pengembangan sistem informasi berbasis komputer. Metode 
SDLC menggunakan pendekatan yang disebut pendekatan air terjun (waterfall approach), yang menggunakan beberapa tahapan dalam mengembangkan sistem. Tahap tersebut dinamakan waterfall karena pada setiap tahapan sistem akan dikerjakan secara berurut menurun dari satu ke tahap yang lain seperti dijelaskan pada gambar berikut.

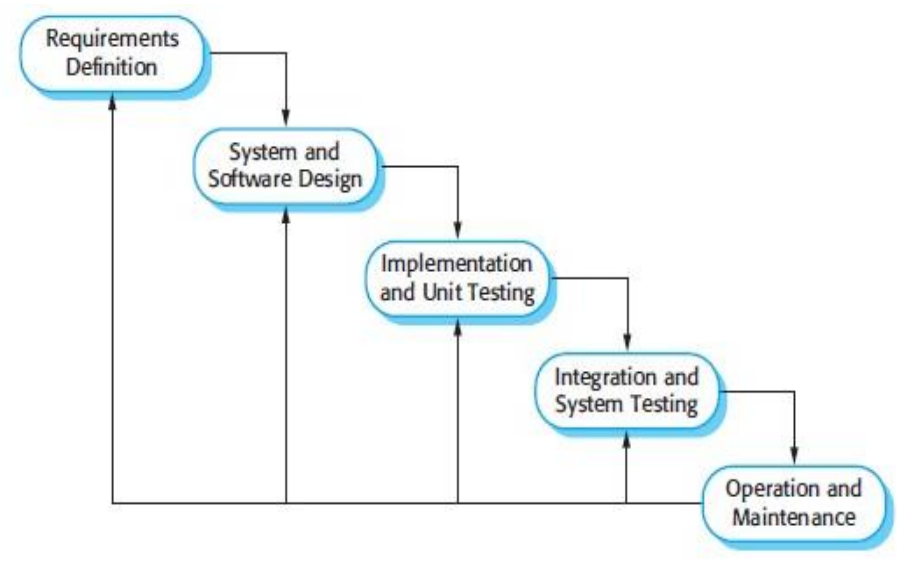

Figure 1. Model proses pengembangan sistem

\section{Result and Discussion}

Berikut ini merupakan alur dari proses algoritma boxblur dimana dalam implementasiannya, algoritma ini melakukan proses kompresi citra dengan mengurangi ketajaman gambar yang telah diunggah. Untuk mendapatkan nilai dari hasil kompresi boxblur, pertama yang dilakukan adalah mengubah file citra menjadi array 2D yang berisikan nilai piksel. Berdasarkan rumus:

$S[i, j]=\sum_{k=-r}^{+r} C[i, j+k]$

kemudian ambil matrix array (digunakan $3 \times 3$ ) untuk awal piksel dan hitung total warna. Untuk menghitung matrix array dilakukan dengan menggunakan rumus

$$
\text { warna final }=\frac{\text { total warna }}{\text { jumlah piksel }}
$$

dan simpan warna hasil perhitungan pada posisi piksel saat ini. Pertama, hitung total warna $=$ total warna - (warna piksel -1$)$, total warna = total warna + (warna piksel +1$)$, dan yang terakhir warna final $=\frac{\text { total warna }}{2 \times 1+1}$ kemudian simpan. Setelah dilakukan satu perhitungan, ulangi langkah-langkah perhitungan hingga semua matrix selesai dan simpan matrix array 2D menjadi file citra.

Pada halaman tulis pengaduan, terdapat tujuh kolom isian yaitu judul pengaduan yang berfungsi sebagai pemberian judul yang tepat dari pengaduan apa yang ingin diadukan, instansi terkait yang berfungsi sebagai kolom pilihan instansi mana yang cocok dipilih sesuai dengan jenis pengaduan apa yang User adukan, jenis pengaduan yang berfungsi memilih pengaduan jenis apa yang ingin diadukan oleh User berdasarkan pemilihan Instansi yang sudah dipilih sebelumnya, lokasi pengaduan yang berfungsi memberikan informasi lokasi dimana keluhan tersebut diadukan, isi pengaduan yang berfungsi memberikan tambahan informasi yang lebih rinci seputar pengaduan yang diadukan, gambar yang berfungsi memperjelas pengaduan apa yang nantinya akan ditindaklanjuti oleh Instansi berupa foto yang dapat langsung diunggah oleh User, peta yang berfungsi memberikan titik koordinat letak pengaduan dimana lokasi yang diadukan berada. 


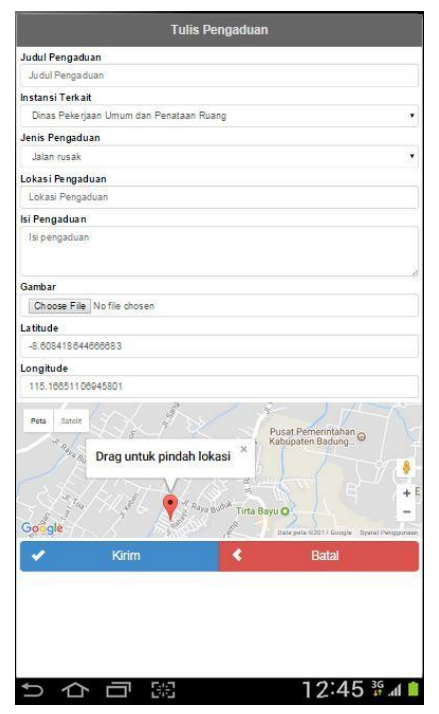

Figure 2.Tampilan antarmuka tulis pengaduan

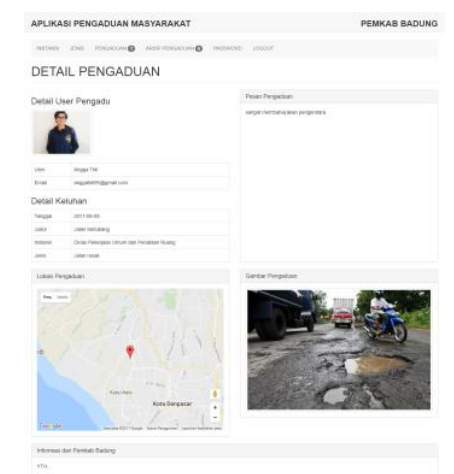

Figure 3.Tampilan antarmuka detail pengaduan

\section{Black Box Testing}

Pengujian dengan metode ini dilakukan hanya mengamati hasil eksekusi melalui data uji dan memeriksa fungsional dari sistem yang dibuat.

Table 1. Checklist kebutuhan black box testing

\begin{tabular}{cccc}
\hline $\begin{array}{c}\text { Kode } \\
\text { Kebutuhan }\end{array}$ & Daftar Uji & Pengguna & Status \\
\hline KF 1 & Registrasi & User & Terpenuhi \\
KF 2 - A & Login Sistem & User & Terpenuhi \\
KF 2 - B & Login Sistem & $\begin{array}{c}\text { Admin Pemkab } \\
\text { Badung }\end{array}$ & Terpenuhi \\
& & & \\
KF 2 - C & Login Sistem & Admin Instansi & Terpenuhi \\
KF 3 & Edit Profil & User & Terpenuhi \\
KF 4 & Tulis Pengaduan & User & Terpenuhi \\
KF 5 & Informasi & User & Terpenuhi \\
\hline
\end{tabular}




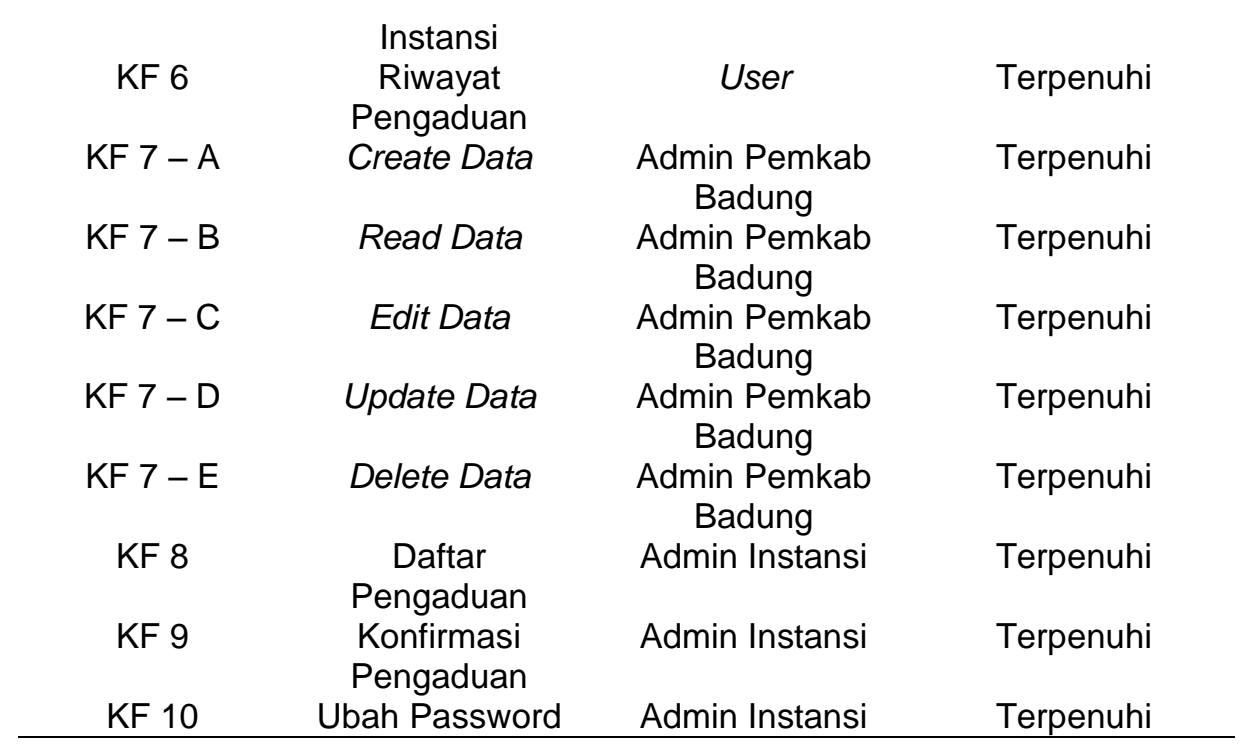

\section{Stress Testing}

Stress Testing pada penelitian ini dilakukan dengan menggunakan tools Webserver Stress Tool 8, laptop dengan spesifikasi CPU Intel ${ }^{\circledR}$ Core $^{\mathrm{TM}}$ Core i7 $-4700 \mathrm{HQ}-3.4 \mathrm{GHz}$, RAM $4 \mathrm{~GB}$ DDR3 dengan OS Windows 7. Tipe testing yang dilakukan adalah Click Test Type, dengan ketentuan setiap pengguna melakukan click test sebanyak 20 klik dengan delay waktu tiap klik selama 3 detik. Pada penelitian ini, pengujian dilakukan dengan jumlah pengguna mulai dari 50 , $100,200,300,400,500,600,700,800,900,1000,1100,1200,1300,1400$, dan 1500 pengguna. Pengujian ini dilakukan untuk memperoleh perbedaan rata-rata jumlah error dan jumlah pengguna dengan cara mendapatkan waktu tunggu klik yang terjadi ketika adanya kegagalan dalam request pada URL yang telah ditentukan. Error yang dimaksud dalam pengujian ini yaitu jumlah request yang gagal per periode waktu (random times), per click times, per user, per URL.

Hasil dari stress testing ini yaitu tingkat error terkecil sebesar $0 \%$ didapatkan jika sistem diakses kurang dari 700 User, ditemukan error saat diakses 800 User mencapai 6,48\% dan tingkat error terbesar sebesar 25,63\% pada saat sistem diakses oleh 1500 User. Rata rata Click Time atau rata-rata waktu klik yang dihasilkan per pengguna dengan menggunakan percobaan user dari 50 user sampai dengan 1500 User dengan waktu tunggu masih kurang dari 10 detik sehingga disimpulkan bahwa 1500 user belum mempengaruhi kinerja sistem.

\section{Penurunan Kompresi}

Dalam Tabel penurunan kompresi atau Saving Precentages (SS) dilakukan perhitungan untuk mengetahui persentase penurunan ukuran gambar dengan satuan ukuran kilobyte (kb) setelah dilakukan proses kompresi dari ukuran file asli menjadi file yang telah terkompresi. Persentase penurunan ukuran file gambar tersebut dihitung dengan cara:

$$
S S=\frac{\text { Ukuran file asli }- \text { Ukuran file hasil kompresi }}{\text { Ukuran file asli }} \times 100
$$

Dalam mencari persentase penurunan kompresi ini, dilakukan dengan mengambil 9 sample gambar yang diunggah User pada saat dilakukan proses pengaduan dengan hasil yang telah didapatkan dan dapat dilihat pada tabel berikut : 
Table 2. Checklist Kebutuhan Black Box Testing

\begin{tabular}{cccc}
\hline File Gambar & $\begin{array}{c}\text { Ukuran file asli } \\
(\mathrm{kb})\end{array}$ & $\begin{array}{c}\text { Ukuran file hasil } \\
\text { kompresi }(\mathrm{kb})\end{array}$ & $\begin{array}{c}\text { Lama proses } \\
\text { kompresi (s) }\end{array}$ \\
\hline Gambar 1 & 3300 & 49.7 & 1 \\
Gambar 2 & 5650 & 72.7 & 1 \\
Gambar 3 & 5430 & 245 & 1 \\
Gambar 4 & 5220 & 77.2 & 1 \\
Gambar 5 & 4840 & 209 & 1 \\
Gambar 6 & 2540 & 114 & 1 \\
Gambar 7 & 2710 & 108 & 1 \\
Gambar 8 & 3380 & 417 & 1 \\
Gambar 9 & 2670 & 105 & 1 \\
Rata-rata & 95.79 & & \\
\hline
\end{tabular}

\section{Conclusion}

Berdasarkan hasil penelitian ini, maka dapat diperoleh kesimpulan antara lain :

1. Masyarakat dapat memberikan pengaduan dengan memberikan informasi yang mendetail karena dalam menuliskan pengaduan masyarakat menyertakan keterangan singkat aduan pada kolom isi pengaduan, dapat mengunggah foto bukti yang akan diadukan, dan alamat lokasi pengaduan.

2. Implementasi algoritma Boxblur pada Sistem Informasi Pengaduan Masyarakat berbasis Mobile berhasil diimplementasikan. Dengan diimplementasikannya algoritma Boxblur pada sistem, dapat mengurangi beban server dengan meminimalkan ukuran gambar yang dikirim oleh client namun gambar masih dapat terlihat dengan sangat jelas.

\section{References}

[1] Anofrizen, "Sistem Informasi Pengaduan Masyarakat Program Keluarga Harapan Kota Pekanbaru (Studi Kasus: Dinas Sosial Dan Pemakaman Kota Pekanbaru)," Jurnal IImiah Rekayasa dan Manajemen Sistem Informasi, Vol. 3, No. 1, Februari 2017

[2] Ellya Nurfarida, "Implementasi Web Service untuk Sistem Pengaduan Masyarakat di Lingkungan Pemerintah Kota Kediri," Jurnal Informatika dan Multimedia, Vol. 06, No. 01, Tahun 2014

[3] I. H. WITTEN; et al. "Semantic and Generative Models for Lossy Text Compression" (PDF). The Computer Journal. Retrieved 2007-10-13

[4] Sommerville, lan. 2011. Software Engineering (Rekayasa Perangkat Lunak). Jakarta: Erlangga. 